\title{
The Analysis Factor of Medical Tourism in Singapore
}

\author{
Martin Lianto ${ }^{1}$, Widjojo Suprapto ${ }^{1 *}$, and Maizirwan $\mathrm{Mel}^{2}$ \\ ${ }^{1}$ Department of Management, Faculty of Business and Economics, Petra Christian University, \\ Jl. Siwalankerto 121-131, Surabaya 60236 Indonesia \\ ${ }^{2}$ Department of Biotechnology Engineering, Faculty of Engineering, International Islamic University \\ Malaysia, 50728 Kuala Lumpur, Malaysia
}

\begin{abstract}
Indonesian citizens have spent the USD $11.5 \times 10^{9}$ for medical treatment services abroad. Singapore is one of the favorite countries in medical tourism for Indonesian people. This research aims at analyzing the attraction factors of medical tourism in Singapore. There are 100 respondents visited Singapore to do medical tourism. The retrieved data is processed using the CFA (confirmatory analysis factor) method. The result shows the five main factors that make Singapore attractive for medical tourism, and the factors are the atmosphere and medical accuracy, competency and price, facilities, customer satisfaction, and entertainment.
\end{abstract}

Keywords: Health tourism, tourist destination, destination attractiveness

\section{Introduction}

Traveling abroad for medical care to various international locations is common and not new phenomena. Nowadays, medical tourism has become a big interest value in a new tourism category [1]. Medical tourism has become a choice to do medical care and it grows rapidly. These phenomena are a combination of medical activities and tourism that gives positive influences for the investment of the economy and health in a country. It contributes to the employment, foreign exchange earnings, infrastructure, health, and quality standard of the destination country. Some countries all over the world start to promote medical tourism to get benefits [2].

Sultana et al. add that medical tourism is a complex idea. This includes the good quality of medical care services, and some other supporting facilities, such as a decent accommodation, shopping center, and even recreation setting [1]. The phenomena are that the people of the developed and developing countries visit the destination country for medical purposes [3]. The medical tourism destination is not always in the western or European countries. The main reason for this is the long waiting time to obtain a visa for medical services in most western countries. At the same time, the expenses are expensive and often not covered by insurance. The countries in Asia attracts more visitors than other destinations because the price is lower than the United States or European countries [4].

\footnotetext{
${ }^{*}$ Corresponding author: joe.suprapto@petra.ac.id
} 
Most of the Asian countries have lower labor costs. Medical travelers or international customers can save $40 \%$ to $60 \%$ of their medical expenses.

Ganguli and Ebrahim explain that medical tourism refers to tourism practice to get a health care facility. About 50 countries officially state that medical tourism is their national industry [5]. Medical tourism helps to build world peace and better understanding between developing countries because tourism is the best way to communicate [6]. Some college student volunteers, researchers, and medical trainees from developed countries help to work in third world countries.

The general procedures of medical tourism are, firstly, the individual who wants to do medical care abroad contact the medical tourism service provider [7]. The provider will ask for the details of the patient, such as medical reports, symptoms, medical records, diagnosis, local doctor's opinion and the other relevant information. If the review has been done, the procedure will be continued by the doctor or certified medical consultant that gives information to the patient about medical care. The finance determines the patient in choosing the designated hospital and it also determines how long to stay. The patient who signs the agreement will get a recommendation letter for a medical visa issued by the related embassy. If the requirements and formality have been completed, it will be continued by visiting the destination country. The hospital will take care of all the patient needs from accommodation, treatment, or even post medical care. After the treatment, the patient will go back to the home country. Regularly, the patient can go back to the destination country for some post-treatment cares [8].

According to the Laws of Republic Indonesia number 36, the year 2009 about health, it explains that health care consists of some types; preventive, curative and rehabilitative [9]. Preventive health care is an activity to prevent a problem or illness. These preventive action examples are vaccines, consultation of lifestyle to reduce health risk, unlike curative health that aims to treat illness. Curative health care is an activity and/or a series of treatment activities that aim at healing, suffer reducing, disability controlling to make the quality of life of the patient is optimally maintained. Medical check-up activity is categorized in both depending on the purpose. If the patient wants to know the health profile, it is categorized as preventive. If the patient wants to analyze the health profile for diagnostic considerations, it is categorized as curative. In medical tourism, both treatments are common. For rehabilitative care, it is also possible, for example, providing rehabilitative care for such patients as drug addicts.

In the journal of Horowitz and Rosensweig, they state that medical tourism is a trend growing rapidly where patients from industrial countries are looking for health care in developed countries through the service offered by the community of the countries [7]. The medical tourism definition sometimes is used in referencing all medical care, and it is believed that these phenomena are different from traditional international medical traveling. In the traditional model, the patient of developing countries country goes to the main medical centers of developed countries for advanced medical care. This is encouraged by some help of an organized treatment system and makes medical tourism rapidly growing for patient medical care.

The rapid growth of the medical tourism industry is of the escalating demands of lifestyle changes which cause various lifestyle-related illnesses [10]. Some countries like Thailand, Singapore, and India have been the three leading countries of the medical tourism industry, which they are predicted to control medical treatment industries in Asia about 80 $\%$ in the future [5]. The growth of medical tourism is reported by $20 \%$ increases per year.

For European markets, medical tourism activity is dominated by Canada, England, and Israel. The index shows that the number is not much different from Singapore and India, which are the destinations for Asian countries [11]. Southeast Asia is the center of the industry growth of Asia. Thailand records $1.28 \times 10^{6}$ foreign patients visiting hospitals to 
receive medical treatment. Malaysia also records the number of foreign patients increasing three times during 2001 to 2006. In Singapore, about 410000 foreign visitors come to do the treatment. Ormond and Sulianti explain that the phenomenon of Southeast Asia's rapid growth in the medical tourism industry is because of the significant growth in infrastructure and the high investment of the country [6]. The development of technology and communication give access to health and logistics activity. The rapid growth in the medical tourism industry has been a catalyst that increases global economic growth in Asia.

For Southeast Asia markets, Singapore and Malaysia have been the most popular medical tourism destinations. Ganguli and Ebrahim state that Singapore's income from the medical tourism industry is estimated at about USD $1.6 \times 10^{9}$ in $2016,13.6 \%$ from CAGR [5]. The high-income streams from the Southeast Asia medical tourism industry Indonesia contribute a lot to this. Indonesian patients spend the USD $11.5 \times 10^{9}$ for medical treatment abroad. Kompas newspaper reported in 2018, $1.7 \times 10^{6}$ Indonesian patients do medical treatment abroad. It is estimated that Indonesia accounted for foreign exchange of about USD $100 \times 10^{12}$ per year for the high number of Indonesian traveling to do medical tourism abroad. Another finding, the number of Indonesian traveling to Penang for medical reasons is 500000 people per year and it will continue to grow [12].

Petriella also adds that World Bank data shows that Indonesian people choose to do medical treatment abroad; it is twice more to Singapore than Malaysia [13]. They have a tendency to choose Singapore because it has more attraction values, whether it is medical or tourism. Singapore and Malaysia are the main destination at the moment for Indonesian people to do their medical treatment and traveling abroad [14].

Ganguli and Ebrahim explain that the attractions of medical tourism in Singapore have some factors. Service is one of the factors Indonesian travelers look for in Singapore [5]. Some simple procedures and special complicated surgery such as cardiac surgery, dental surgery, joint replacement (knee/hip) the and cosmetic surgery are the next factors. Various health care, including alternative treatment, psychiatric, recovery and even funeral service, is also available. The government of Singapore sets some strategies to increase the country's foreign exchange from the medical tourism sector. One strategy is called seven pillars that consists of seven main points as a drive to stimulate the sector. This strategy is built to increase the attraction of medical tourism by increasing tourism locations and supporting infrastructure.

Singapore is a city-country with a small population, so it is possible to determine the implementing of the cost for individual and corporate medical treatment. The government targets to invite one million medical tourists. In 2012, there are 850000 medical tourists as reported by Singapore Tourism Board and it has been evaluated critically by the medical tourism organization [15]. IMTJ (International Medical Treatment Journal) argues that the number includes the members of the family and local expats. Therefore, it's only about 200000 of the patients and $47 \%$ is from Indonesia and $12 \%$ is from Malaysia [7].

Singapore Department of Health builds Singapore Medicine, industrial partnerships with the government in 2003. This purpose is to increase industrial, medical tourism and to strengthen the image of the medical center of Asia [15]. The strategy of Singapore medical tourism is built on high quality, trustworthy, and 21 accredited hospitals that have joined JCI (Joint Commission International). Singapore puts the efforts to provide health systems and facilities for its citizens, such as providing the most sophisticated high-end diagnostic equipment available in the market.

Widely spoken English, clean and safe neighborhood, and a stable political situation attract medical tourists to Singapore [15]. This condition gives benefits to international patients, but the excessive dependency on foreign doctors will become a threat when the doctors go back to the home country or move to another place because of social and economic reasons [5]. 
Sultana et al. describe that there are four main factors shaping medical tourism attraction in Singapore [1]. The first factor is Destination Competitiveness, which includes climate, environment, flora and fauna, health area and medical care, heritage or historical attractions, events, transportation, government policy, the quality of actual management and skill of workers. A good location is also considered as the Destination Competitiveness.

The second factor is Service Quality, which covers Reliability, Tangibility, Empathy, Responsiveness, and Assurance [1]. The destination country is required to provide medical tourists with a good quality of service and performance. Service quality is also proved to become a strong competitive factor that attracts tourists, including medical care. The quality of service organization is more than just the application of the mere management quality to all the organizations.

The third factor is the Tourist Attitude that is the culture of the destination country, manners, or social norms used by the destination country, and the language as the consideration of the medical tourists. Income also influences the attraction of medical tourism in Singapore [1].

The fourth factor is the Cost. Consumers are sensitive about product or service costs [1]. This condition is applicable to all customers especially the price-sensitive ones. The price of each product or service is a key element to determine customer satisfaction. Medical fees, accommodation cost, food cost and transportation cost is also in this fourth factor.

The number of Indonesian citizens doing medical tourism in Singapore is relatively high as Singapore keeps on offering new development on general infrastructures and tourist attractions [16]. The high number of medical tourism from overseas raises the topic of how Singapore offers and develops medical tourism as a mainstream of foreign exchange income. This is the main reason in this research to analyze the factors that attract medical tourism in Singapore for Indonesian markets.

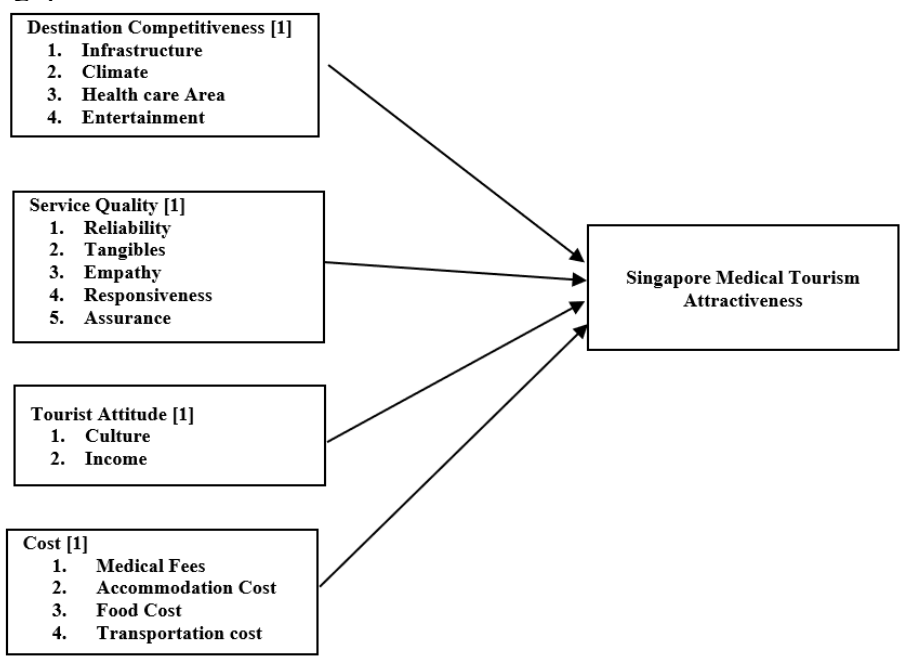

Fig. 1. Research framework

\section{Research method}

The type of this research is quantitative. This research uses quantitative analysis in identifying the factors of consumer decision in choosing Singapore as a medical destination. The population of this research is all Indonesian consumers that have done medical tourism in Singapore. From the population, the sample is drawn with such criteria as the age of 17 and above, visiting Singapore at least two times for medical purposes, and intending to another medical and pleasure tourism in the near future. In this research, 
minimum samples are 96 respondents. The data are collected from the respondents using some questionnaires which are constructed using Likert scales of five levels from strongly disagree to strongly agree [17]. Then, the data are processed to obtain descriptive statistics. Descriptive statistics is a statistic that has a function to describe or give descriptions to the object of the research through sample data or population as it is, without analyzing and concluding that applies to the public. Descriptive statistics used in this research are minimum value, maximum value and average value. The data analysis method for this research is the factor analysis [18].

\section{Analysis and discussion}

\subsection{Descriptive mean analysis}

The descriptive mean analysis aims to describe or depict data in a frequency table. Table 1 shows the result of the motivation for conducting medical tourism in Singapore.

Table 1. The result of mean motivation $\left(\mathrm{X}_{1}\right)$

\begin{tabular}{|c|l|c|c|}
\hline Factor & \multicolumn{1}{|c|}{ Statement in my opinion } & Mean & SD \\
\hline F1 & Access to the medical treatment area and tour area are easy & 3.82 & .80 \\
\hline F2 & Public transportation is fast & 3.90 & .83 \\
\hline F3 & The weather is the same, so no need to adapt & 4.08 & .72 \\
\hline F4 & The medical treatment center is easy to find the address & 4.04 & .83 \\
\hline F5 & The medical treatment area is close to various tour attractions & 3.94 & .88 \\
\hline F6 & $\begin{array}{l}\text { Singapore provides many entertainment places around the medical treatment } \\
\text { location such as amusement park, food center, and mall }\end{array}$ & 3.94 & .87 \\
\hline F7 & Singapore offers many attractions such as festivals or performances & 3.86 & .89 \\
\hline F8 & The medical treatment system gives accurate illness diagnostic & .86 \\
\hline F9 & Medical treatment has a high success level & 4.05 & .74 \\
\hline F10 & The medical tools and equipment are modern and comprehensive & 4.17 & .73 \\
\hline F11 & The rooms and buildings are nicer & 4.09 & .75 \\
\hline F12 & $\begin{array}{l}\text { Medical professionals in Singapore seriously listen to patient's complaints } \\
\text { thoroughly }\end{array}$ & 4.14 & .77 \\
\hline F13 & Medical workers in Singapore have high skills & 4.29 & .75 \\
\hline F14 & Singapore uses international language to make it easier for tourists & 4.10 & .70 \\
\hline F15 & Singapore has the same cultural mannerism more or less & 4.27 & .73 \\
\hline F16 & Consumers who do medical tourism to Singapore have a high income & 4.15 & .80 \\
\hline F17 & Singapore provides optional payments with insurance & 4.05 & .82 \\
\hline F18 & Medical treatment in Singapore is as good as the quality of the treatment received & 3.93 & .80 \\
\hline F19 & There are some optional prices for the types of accommodation & 4.12 & .80 \\
\hline F20 & Public transportation is as good as the quality of the transportation itself & 4.12 & .70 \\
\hline F21 & The food price in Singapore is various & 4.16 & .70 \\
\hline & Total & 4.05 & .42 \\
\hline
\end{tabular}

The result of the analysis shows that, based on the Confirmatory Analysis Factor method, there are five main factors recognized to form the attractions of medical tourism in Singapore.

Table 2. Rotated component matrix

\begin{tabular}{|l|l|l|l|l|l|}
\hline \multirow{2}{*}{ Factor } & \multicolumn{5}{|c|}{ Number Component Matrix } \\
\cline { 2 - 6 } & $\mathbf{1}$ & $\mathbf{2}$ & $\mathbf{3}$ & $\mathbf{4}$ & $\mathbf{5}$ \\
\hline F1 & .460 & .143 & -.014 & -.013 & $\mathbf{. 5 9 8}$ \\
\hline F2 & $\mathbf{. 5 2 6}$ & -.040 & .025 & .157 & .322 \\
\hline F3 & $\mathbf{. 6 8 8}$ & .024 & .036 & .284 & .042 \\
\hline F4 & $\mathbf{. 7 7 5}$ & .138 & .150 & -.041 & -.031 \\
\hline F5 & $\mathbf{7 8 7}$ & .067 & .026 & .006 & .233 \\
\hline F6 & $\mathbf{. 8 0 8}$ & -.014 & .132 & -.061 & .039 \\
\hline F7 & .322 & .091 & .226 & .131 & $\mathbf{. 6 8 9}$ \\
\hline
\end{tabular}




\begin{tabular}{|l|l|l|l|l|l|}
\hline \multirow{2}{*}{ Factor } & \multicolumn{5}{|c|}{ Number Component Matrix } \\
\cline { 2 - 6 } & $\mathbf{1}$ & $\mathbf{2}$ & $\mathbf{3}$ & $\mathbf{4}$ & $\mathbf{5}$ \\
\hline F8 & $\mathbf{. 5 3 8}$ & .116 & .280 & .042 & .390 \\
\hline F9 & .231 & .374 & $\mathbf{. 4 9 0}$ & .211 & .087 \\
\hline F10 & .332 & .058 & .123 & $\mathbf{. 5 2 6}$ & .307 \\
\hline F11 & .125 & .072 & $\mathbf{. 9 0 6}$ & .154 & .145 \\
\hline F12 & .061 & .272 & .195 & $\mathbf{. 8 8 7}$ & .088 \\
\hline F13 & .060 & $\mathbf{. 5 6 0}$ & .241 & .198 & .414 \\
\hline F14 & -.002 & .360 & .245 & .073 & $\mathbf{. 5 3 2}$ \\
\hline F15 & .044 & $\mathbf{. 4 7 7}$ & .457 & .218 & .136 \\
\hline F16 & .049 & $\mathbf{. 5 9 3}$ & .056 & .212 & .206 \\
\hline F17 & -.044 & $\mathbf{. 6 9 9}$ & -.077 & .051 & .287 \\
\hline F18 & .119 & $\mathbf{. 7 8 3}$ & .069 & -.034 & .015 \\
\hline F19 & .060 & $\mathbf{. 7 4 9}$ & .161 & .287 & -.291 \\
\hline F20 & .139 & .024 & $\mathbf{. 9 0 9}$ & .101 & .123 \\
\hline F21 & -.030 & .202 & .156 & $\mathbf{. 9 1 0}$ & -.018 \\
\hline
\end{tabular}

\subsection{Discussion}

The result from Table 2. is assembled into new groups, which can be seen in Table 3.

Table 3. New factor naming

\begin{tabular}{|c|c|c|}
\hline Factor & Element & Factor Statement \\
\hline 1 & $\begin{array}{l}\text { Atmosphere \& } \\
\text { Medical } \\
\text { Accuracy }\end{array}$ & $\begin{array}{l}\text { 1. In my opinion, public transportation is fast to visit a wanted place } \\
\text { 2. In my opinion, the weather is the same, so no need to adapt } \\
\text { 3. In my opinion, the medical treatment area is close to various tour } \\
\text { attractions } \\
\text { 4. In my opinion, Singapore provides many entertainment places around the } \\
\text { medical treatment location such as amusement park, food center, and mall } \\
\text { 5. In my opinion, the medical treatment system gives accurate illness } \\
\text { diagnostic }\end{array}$ \\
\hline 2 & $\begin{array}{l}\text { Competency } \\
\text { Price }\end{array}$ & $\begin{array}{l}\text { 1. In my opinion, medical workers in Singapore have high skills } \\
\text { 2. In my opinion, Singapore has the same cultural mannerism more or less } \\
\text { 3. In my opinion, consumers who do medical tourism to Singapore have a } \\
\text { high income } \\
\text { 4. In my opinion, Singapore provides optional payments with insurance } \\
\text { 5. In my opinion, medical treatment in Singapore is as good as the quality of } \\
\text { the treatment received } \\
\text { 6. In my opinion, there are some optional prices for the types of } \\
\text { accommodation }\end{array}$ \\
\hline 3 & Facility & $\begin{array}{l}\text { 1. In my opinion, medical treatment has a high success level } \\
\text { 2. In my opinion, the rooms and buildings are nicer } \\
\text { 3. In my opinion, public transportation is as good as the quality of the } \\
\text { transportation itself (cheap, fast, safe and clean) }\end{array}$ \\
\hline 4 & $\begin{array}{l}\text { Customer } \\
\text { satisfaction }\end{array}$ & $\begin{array}{l}\text { 1. In my opinion, the medical tools and equipment are modern and } \\
\text { comprehensive } \\
\text { 2. In my opinion, medical professionals in Singapore seriously listen to } \\
\text { patient's complaints thoroughly } \\
\text { 3. In my opinion, the food price in Singapore is various }\end{array}$ \\
\hline 5 & Entertainment & $\begin{array}{l}\text { 1. In my opinion, access to the medical treatment area and tour area are easy } \\
\text { 2. In my opinion, Singapore offers many attractions such as festivals or } \\
\text { performances } \\
\text { 3. In my opinion, Singapore uses international language to make it easier for } \\
\text { tourists }\end{array}$ \\
\hline
\end{tabular}


Factor 1 is shaped from a combination of factors that reflects the fast public transportation to the destination, the same weather condition from the origin country that no need to adapt, medical treatment center easy to find, medical treatment area located near to various tourist attractions, many entertainment places around the medical treatment location such as amusement park, food center, and mall, medical treatment system giving accurate illness diagnostics. In this case, factor 1 describes the ease that the visitors feel to use public facilities, the friendly weather, easy to find location, and location near to attractions. Factor 1 is related to the medical treatment description in general because it represents both medical and tourism needs at the same time. Based on the explanation above, factor 1 is named Atmosphere and Medical Accuracy.

Factor 2 is shaped from element factors that reflect the medical workers in Singapore having higher skills, the same cultural mannerisms more or less, high income to afford the treatment, insurance payment option for medical cost, the price as good as the quality, and various accommodations with many prices ranges choices. The second factor is related to the same mannerism in both countries and the readiness described in the income level or insurance support. Based on the descriptions above, factor 2 is named Competency \& Price.

Factor 3 reflects the respondents' confidence about the high success rates of medical treatment in Singapore, the nicer building, the good quality of the public transport (cheap, fast, safe, and clean). Factor 3 is related to the attraction of medical treatment offered by the Singapore government, where the success rates of the medical treatment are high by the support of the government to provide good buildings and public transportation facilities. From the descriptions, factor 3 is named the Facilities factor.

Factor 4 reflects the consumers' view that the tools and the equipment available in Singapore are sophisticated and comprehensive, the medical professionals listen to the patient's condition thoroughly, and the food prices in Singapore are various. Factor 4 reflects the professionalism of the workers and the equipment owned in Singapore. It is clear that the respondents travel to Singapore for medical treatment in hoping the quality of the better workers and equipment compared to Indonesia. Factor 4 is named Customer Satisfaction.

Factor 5 is reflecting the merging factors related to the ease of access to medical treatment and tourist attraction areas, entertaining festivals and performances, and the international language that makes it easy for tourists to visit. Factor 5 reflects the general factors that attract tourists to Singapore, on the medical side is determined from road access. Eventually, factor 5 is named Entertainment.

\section{Conclusion}

This research concludes from the result of analysis and discussion as follows:

(i). From a total of 21 factors estimated to be the medical treatment attractions in Singapore, all are reduced to five main factors: Atmosphere and Medical Accuracy, Competency and Price, Facilities, Customer satisfaction, and Entertainment.

(ii). The Atmosphere and Medical Accuracy Factor is a combination of element statements of public transportation, the weather, the medical treatment area, the entertainment places, and the medical treatment accuracy.

(iii). The Competency and Price Factor is a combination element statements of high skillful medical workers, the same cultural mannerism, the high-income consumers, the optional payment with insurance, the quality medical treatment reflected in the price, and the wide range hotel types.

(iv). The Facilities factor is a combination of element statements of highly successful medical treatment, the facilities, the public transportation 
(v). Customer Satisfaction is a combination of element statement of modern and comprehensive medical equipments, professional medical workers, and various food prices.

(vi). The Entertainment factor is a combination element statement of accessibility to the medical treatment area, many tourist attractions, and several international languages spoken by the locals.

\section{References}

1. S. Sultana, A. Haque, A. Momen, F. Yasmin, Iranian J Publ Health, 43,7:867876(2014). https://www.ncbi.nlm.nih.gov/pmc/articles/PMC4401052/

2. S. Zuhri, I. Suhendrianto, P.D. Sentia, International Conference on Engineering and Science for Research and Development, 1,2:167-175(2015).

https://www.researchgate.net/profile/Prima_Sentia/publication/317568299 The Analy sis of Relationships_Among_Variables Toward_Medical Tourism to Malaysia by Employing_Structural_Equation_Modelling/links/59400ba745851554614a7749/TheAnalysis-of-Relationships-Among-Variables-Toward-Medical-Tourism-to-Malaysiaby-Employing-Structural-Equation-Modelling.pdf

3. J. Connell, Tourism Management, 27,6:1093-1100(2006). https://www.sciencedirect.com/science/article/pii/S0261517705001871

4. H.G. Singh, Journal of Service Science and Management, 4:315-324(2011). http://citeseerx.ist.psu.edu/viewdoc/download?doi=10.1.1.860.2107\&rep=rep1\&type=p $\underline{\mathrm{df}}$

5. S. Ganguli, A.H. Ebrahim, Tourism Management Perspectives, 21,1:74-48(2017). https://www.sciencedirect.com/science/article/pii/S2211973616301155

6. M. Ormond, D. Sulianti, Current Issues in Tourism, 20,1:94-110(2014). https://www.tandfonline.com/doi/abs/10.1080/13683500.2014.937324

7. M.D. Horowitz, J.A. Rosensweig, IMTJ International Medical Travel Journal, 1,2:114(2008).

https://www.researchgate.net/publication/285032774_Medical_tourism_vs traditional international medical travel_A tale of two models

8. S. Banerjee, S.S. Nath, N. Dey, H. Eto, New Business Opportunities In The Growing ETourism Industry. Asia: IGI Global (2015). https://books.google.co.id/books?id=woEfCgAAQBAJ\&dq

9. DepkesRI. Undang-Undang No. 36 Tahun 2009 Tentang Kesehatan. [Law No. 36 of 2009 concerning Health]. [Legal document]. Jakarta: Sekretariat Negara (2009). [in Bahasa Indonesia]. https://www.depkes.go.id/resources/download/general/UU\%20Nomor\%2036\%20Tahu n2\%20009\%20tentang\%20Kesehatan.pdf

10. J. Kumar, K. Hussain, International Interdisciplinary Business-Economics Advancement Journal, 1,1:1-10(2016). https://scholarcommons.usf.edu/cgi/viewcontent.cgi?article $=1000 \&$ context $=$ globe

11. K. M. Wong, P. Velasamy, T.N.T. Arshad, SHS Web of Conferences, 12,1:1-8(2014). https://www.shsconferences.org/articles/shsconf/abs/2014/09/shsconf_4ictr2014_01037/shsconf_4ictr2 014 01037.html

12. L. Fathia, Tidak Hanya Aceh, Banyak Orang Indonesia Memilih Berobat ke Penang. Berikut Alasannya, [Not Only Aceh, Many Indonesians Choose Treatment at Penang. Here are the reasons], [Online] from https://liza-fathia.com/warga-indonesia-berobatke-penang-malaysia/ (2018). [Accessed on May 2, 2019]. [in Bahasa Indonesia]. 
13. Y. Patriella, Setiap Tahun, Rp100 Triliun Melayang karena Pasien RI Berobat di Luar Negeri [Every Year, IDR100 Trillion Is Hovered Because RI Patients Are Treated Overseasretreived], [Online] from https://ekonomi.bisnis.com/read/20180703/12/812357/setiap-tahun-rp100-triliunmelayang-karena-pasien-ri-berobat-di-luar-negeri (2018). [Accessed on May 2. 2019], [in Bahasa Indonesia].

14. M.O. Sulianti, Current Issues in Tourism, 20,1:94-s110(2014). https://www.tandfonline.com/doi/abs/10.1080/13683500.2014.937324

15. J.C.H. Yap, International Hospital Federation Reference Book 2006/2007, Switzerland: IHF-FIH (2006). p. 25-28. https://www.ihffih.org/download_doc_file.php?doc $=469 \mathrm{be} 46 \mathrm{~b} 07 \mathrm{c} 5 \mathrm{e} 91 \mathrm{~d} 7 \mathrm{bce} 0897764 \mathrm{~b} 9 \mathrm{~d} 4 \mathrm{~b}$

16. L.K. Anna, Pasien Indonesia, Turis Medis Terbesar di Singapura [Indonesian Patient, Largest Medical Tourist in Singapore]. [Online] from https://lifestyle.kompas.com/read/2015/04/26/091700723/Pasien.Indonesia.Turis.Medis Terbesar.di.Singapura (2015). [Accessed on May 2. 2019], [in Bahasa Indonesia].

17. S. Lemeshow, D.W. Hosmer, J. Klar, Adequace of Sample Size in Health Studies, USA: World Health Organization (1994). https://apps.who.int/iris/bitstream/handle/10665/41607/0471925179 eng.pdf;sequence $=1$

18. Sugiyono, Statistika untuk penelitian. [Statistics for research]. Bandung: Alfabeta (2018). [in Bahasa Indonesia]. https://www.goodreads.com/book/show/29974706$\underline{\text { statistika-untuk-penelitian }}$ 